\title{
実大振動台実験による柱梁接合部の破壊性状に関する研究 \\ STUDY ON FRACTURE OF BEAM-TO-COLUMN CONNECTIONS BY MEANS OF FULL SCALE SHAKING TABLE TEST
}

\author{
秋山宏*1, 山田 哲*2, 松本由香*3, 松 岡三 郎*4 \\ 小倉桂治*5, 北村春幸*6 \\ Hiroshi AKIYAMA, Satoshi YAMADA, Yuka MATSUMOTO, \\ Saburo MATSUOKA, Keiji OGURA and Haruyuki KITAMURA
}

This study aims at simulating the fracture of beam-to-column connections under the Hyogoken-nanbu earthquake.

Specimens composed of $\mathrm{H}$-shaped beams and box columns were subjected to seismic motions by means of shaking table test, and the ultimate behavior was examined. The following results were obtained.

(1) All specimens showed high deformation capacities and negative effects of dynamic loading were not observed.

(2) High toughness of material reduces the sensitivity to geometrical notch effects and is useful to prevent brittle fracture.

keyword: full scale test, dynamic loading, beam-to-column connections, fracture

実大実験、動的載荷、柱梁接合部、破壊

\section{1 序}

鋼構造剛接骨組は、一般に終局メカニズムとして梁崩壊型を指向 して設計される。この崩壊型が保証されれば、特定層への損傷集中 が楥和され、骨組全体のエネルギー吸収能力は向上する。この場合、 梁端が塑性ヒンジを形成し安定的に塑性変形をすることが重要であ る。

1995年の兵庫県南部地震においては、多くの柱梁剛接接合部に破 壊による被害が生じた。これらの被害の中には、現行の設計基準に 基づいて設計され、従来の標準的な接合詳細を探用した接合部が破

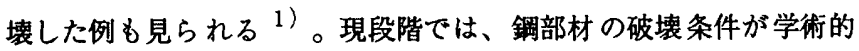
に解明されていないため、これらの接合部が破壊以前に発揮した部 材性能を評価することが困難である。破壊に対する安全性を確保す るためには、鍊部材の破壊条件を解明し、設計時の要求性能の保証、 余力の評価などの問題を解決する必要がある。

破壊現象に影響を及ほす要因は、材料特性や幾何学的形状、寸法 効果、載荷速度など、多岥に亘っている。この場合、個々の要因に
関する分析的な研究とともに、地震時に鎆部材が曝される現実的な 負荷条件の下で諸条件の相互関係を明らかにし、最も致命的な影響 を及涩す要因を特定することが重要である。

建築分野においても、既に破壊現象を再現した多くの実験が報告 されており 2,3）、困難であった奏大部材の動的載街赛験も行われ ている4）。しかし、これらの奏験は任意に設定した載荷速度で正 負交翻載荷を行うもので、地震入力時にどの程度の歪速度が生じる か、という点については解析的な検討にとどまっているのが現状で

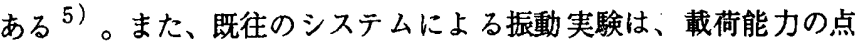
から縮小架構を試験体とする必要があり、寸法効果と歪速度の再現 性に問題がある ${ }^{6) 。}$

このような状況を踏まえ、文献 6 に示寸加振装置が開発され、実 大部材の振動実験が可能になった。本研究は、この加振装置を用い て兵庫県南部地震における柱梁剛接接合部の梁端破壊を再現し、一 般的な鋼構造柱梁接合部の終局 耐震性を明確にすることを意図する ものである。

\footnotetext{
*1 東京大学工学部建築学科 教授・ 工.博

*2 東京工業大学建築物理研究センター- 助教授・ I. 博

*3 東京大学工学部建築学科 大学院生・工修

*4 金属材料技術研究所フロンティア構造材料センター 工博

*5 大成建設設計本部

*6 日建設計東京本社構造設計室 工博
}

Prof., Dept. of Architecture, Faculty of Engineering, Univ. of Tokyo, Dr. Eng. Assoc. Prof., Structurai Engineering Research Center, Tokyo Institute of Technology, Dr. Eng.

Graduate Student, Dept. of Architecture, Faculty of Engineering, Univ. of Tokyo, M. Eng.

National Research Institute for Metals, Frontier Research Center for Structual Materials, Dr. Eng.

Design Division, Taisei Corporation

Structural Engineering Dept., Tokyo Office, Nikken Sekkei Ltd., Dr. Eng. 


\section{2 实跙概墨}

\section{1 江确体の汁面}

本研究では、中層程度の鋼構造骨組の低層部分に使用される部材 を想定している。図 1 に示すように、試験体は骨組の部分架構をモ テル化したT形であり、水平材に柱を想定した角形銅管、垂直材に 梁を想定したH 形銅を用いている。梁端フランジの破壊を再現する ため、試験体は主に梁部分で変形し、柱及びパネル部は弾性に留ま るよう設計した。さらに、局部座屈を防止するため、梁の接合部近 傍に $20 \mathrm{~cm}$ 間隔で 3 筒所スチフナを設けた。

表 1 に試験体一覧、図 2 に接合部詳細を示す。試験体No.2(表中の 網掛计部分）が標準試験体である。

角形鋼管柱に接合された梁部材の変形能力を低減する要因として、 以下の点が指摘されている。

(1) 部材断面における応力伝達上の無効部分

角形鋼管柱と $H$ 形梁接合部について、ウェフのモーメント負担率 が低いものほど部材の变形能力が低くなる実験結果が報告されてい $3^{3)}$ 。

（2）幾何学的形状や負荷状態に起因する応力集中、歪集中

これらの現象を生じさせる代表的な要因として、梁端部に設けら れるスカラップが挙げられる7゙ 。

(3) 部材の寸法効果 ${ }^{8)}$

以上の観点から、本実験のパラメータを次のように設定した。 ・接合部におけるウェブのモーメント負担の影響

一般に、ウェブを柱に溶接した工場溶接タイプは、ウェブをボル 卜接合とした現場接合タイプよりウェブのモーメント負担が大きい。 また、工場溶接タイプでは角形龬管柱の板厚が厚いほど、ウェブの モーメント負担が大きくなる。そこで、工場溶接タイプで柱板厚が 異なる試験体No.1、Na2、No.6、及び現場接合タイプのNo8 比較 対象とする。

・スカラップ形状の影響

既に、スカラップの存在による接合部の耐霞性能の低下を楥和す るため、改良型スカラップ ${ }^{9)}$ やノンスカラップ工法 ${ }^{10 ）}$ が提案さ れている。ここでは、改良型スカラップとしてスカラップ底に半径 $10 \mathrm{~mm}$ 返りをつけたタイフ（試験体No.3）、スカラップ位置を避 けてフランジを溶接するタイプ（試験体No.4）の 2 種、及びノンス カラップタイプ（試験体No.5）を採用し、従来型スカラッブを設け た試験体No.2との比較を意図した。

\section{・フランジ板厚の影響}

試験体No.7の梁については、板厚の厚いるのを使用している。 表 2 に梁材の機械的特性を示す。表中の值は、JIS1A号試験片の 引張試験及びシャルピー試験から得られたものである。図 3 に素材 試験片の採取位置を示す。シャルピー値及び脆性破面率の選移曲線 を図 4 に示す。

接合部の溶接は、現行の標準的な方法で行うことを意図した。表 3 に接合部の溶接条件を示す。溶接方法は $\mathrm{CO}_{2}$ 半自動溶接である。 エンドタブはスチールタブとし、溶接後の切断などの処置は行わな かった。

梁部材の力学的特性について、材料の降伏応力、引張強度と部材 形状から求めた計算值を表 4 に示す。

\section{2 試硂体セットアップ}

図 5 に試験体セットアップ状況を示す。振動台に固定された基礎 梁上のピンで試験体を単純支持し、梁頂部を加力梁端部のピンとPC 棈捧で接続した。文献 6 に示すように、振動台を加振することによっ て重錘に慣性力が生し、梁にせん断力として伝わる仕組みになって いる。

図 5 中に、試験体せん断力、試験体頂部の変位、及びパネル 部隅 角部の変位の計測方法を示す。梁の変形を片持ち梁の変形に換算す ると下式のようになる。

$$
\begin{array}{ll}
\text { 梁の変形: } & \bar{\delta}=\delta-\frac{x 1+x 2}{2}+\frac{y 1-y 2}{\ell} \cdot L v \\
\text { 部材角 }: & \theta=\frac{\bar{\delta}}{L v}
\end{array}
$$

$L v ：$ 水平材上面から試験体頂部の変位計測点までの距離

$\ell:$ パネル部隅角部間の距離

$\delta:$ 試験体頂部の変位

$\mathrm{x} 1, \mathrm{x} 2, \mathrm{y} 1, \mathrm{y2}:$ 図 5 中に示すパネル部隅角部の变位

\section{3 加振方法}

先ずパルス波を入力し、振動系の初期状態における固有周期、隇 衰の大きさなどを確認した。その後、神戸海洋気象台NS波に加速度 倍率を乗して強度レベルを調整した地震波を入力した。加振は弾性 䡉囲での挙動を確認するための弾性加振、全塑性耐力を確認するた めの弾塑性加振、梁端破壊の再現を目標とする終局加振の 3 段階 4 ) に分けて行った。各加振における振動台の最大速度はそれぞれ 10kine、20kine、100k ineである。試験体を含む加振装置は 1 質点系

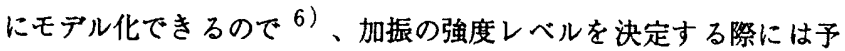
め応答解析を行い、試験体が目標とする状態に到達する程度の入力 になるように加速度倍率を設定した。終局加振時の気温は $13 \sim 18^{\circ} \mathrm{C}$ であった。図 4 から分かるように、この温度においては梁のシャル ピー値は遷移曲線の上部棚に到達している。

\section{3 実験結果}

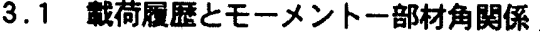

いずれの試験体も、弾性加振時にはほほ弾性範囲に留まり、弾塑 性加振時においてやや塑性化した。試験体No.2について、弾性加振 時、弾塑性加振時の梁端部におけるモーメントと部材角の関係を図 6 及び図 7 に示す。

各試験体の終局加振について、梁端部におけるモーメントと部材 角の関保を図 8 に示す。図中、梁端破壊が生じた点をマで示す。 試験体No.5,6については 1 回の終局加振では梁端破壊に至らず、 2 回の終局加振を要した。試験体No.7の加振では、1 回目の終局加 振の途中で制御系に過電流が流れ、振動台が緊急停止したため、 $15 \mathrm{~cm}$ 程度の残留変形が生じた。残留変形を解除するために、台上最 大速度を40kineとし、加速度の正負を逆転させた地震波を 2 回入力 した後、終局加振を再度行った。このときは振動台が緊急停止する ことを避けるため、台上最大速度を90kineとして正負を逆転させた 地震波を入力した。 


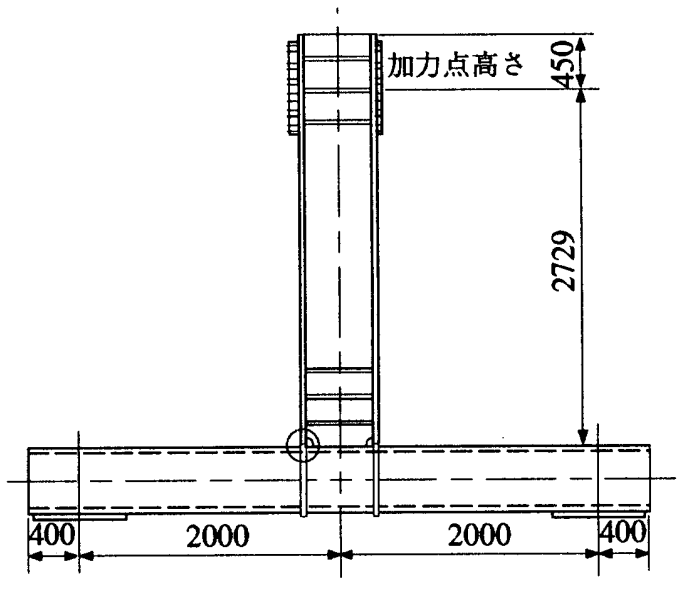

図 1 尌験体形状

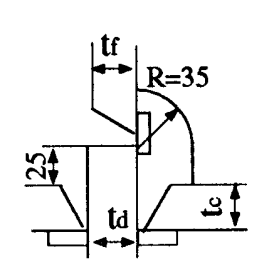

\begin{tabular}{|c|c|c|c|}
\hline 試験体 & tf & tc & td \\
\hline No.1 & 25 & 16 & 28 \\
\hline No.2 & 25 & 22 & 28 \\
\hline No.6 & 25 & 32 & 32 \\
\hline No.7 & 32 & 32 & 36 \\
\hline
\end{tabular}

(1) 試験体No.1, 2, 6,7

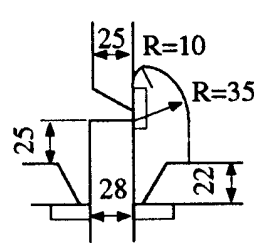

(2) 試験体No.3

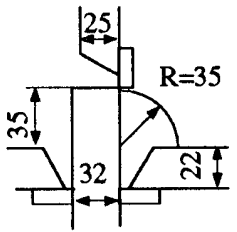

(3) 試験体No.4

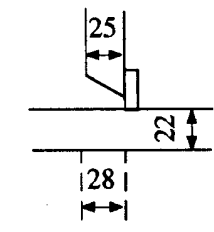

(4) 試験体No.5

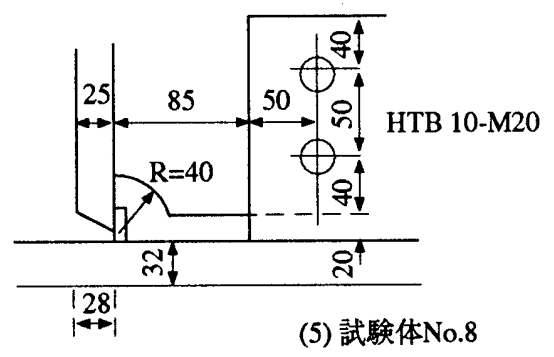

图 2 接合部詳細

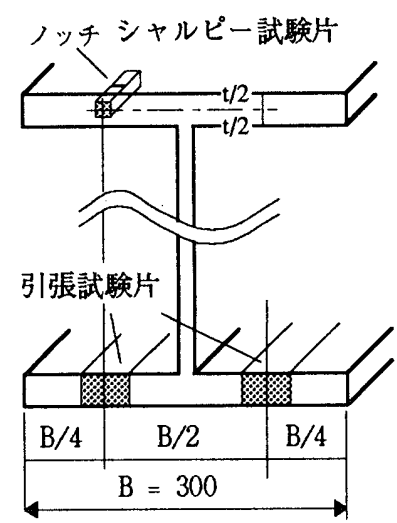

図 3 素材試験片採取位置
表 1 試験体一覧

\begin{tabular}{|c|c|c|c|c|}
\hline 陚験体 & 垂直材 & 水平材 & 形式 & スカラップ \\
\hline No.1 & RH $-600 \times 300 \times 12 \times 25$ & RBox $-500 \times 500 \times 16$ & 工場 & 従来型 \\
\hline vo.2. & $\mathrm{RH} 600 \times 300 \times 12 \times 25$ & $\mathrm{RBO} \times 500 \times 500 \times 22$ & 10 揚: & 進来型 \\
\hline No.3 & RH $-600 \times 300 \times 12 \times 25$ & RBox $-500 \times 500 \times 22$ & 工場 & 改良 1 \\
\hline No.4 & $\mathrm{RH}-600 \times 300 \times 12 \times 25$ & RBox $-500 \times 500 \times 22$ & 工場 & 改良 2 \\
\hline No. 5 & RH $-600 \times 300 \times 12 \times 25$ & BBox- $500 \times 500 \times 22$ & 工場 & 無 \\
\hline No.6 & RH $-600 \times 300 \times 12 \times 25$ & PBox $-500 \times 500 \times 32$ & 工場 & 従来型 \\
\hline No.7 & $\mathrm{BH}-600 \times 300 \times 16 \times 32$ & PBox- $500 \times 500 \times 32$ & 工場 & 従来型 \\
\hline No.8 & RH- $600 \times 300 \times 12 \times 25$ & RBox $-500 \times 500 \times 22$ & 現場 & 従来型 \\
\hline
\end{tabular}

表 2 梁材の材料特性

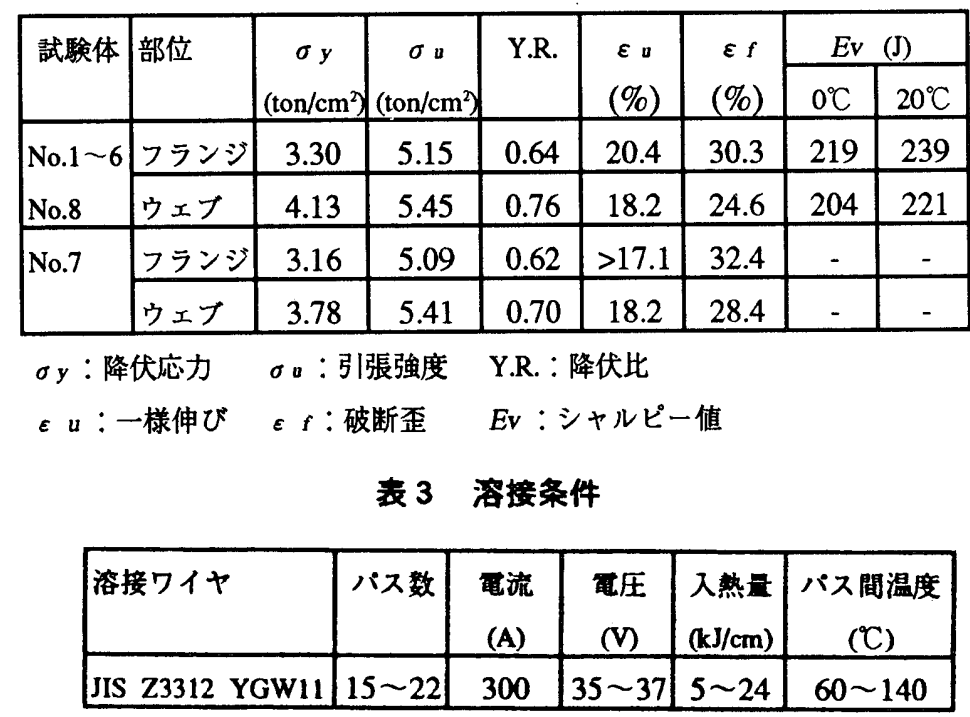

表4 梁部材の力学的特性（計算值）

\begin{tabular}{|c|c|c|c|c|c|}
\hline 試涘体 & $\begin{array}{c}\mathrm{Ke} \\
(\operatorname{tonf} / \mathrm{cm})\end{array}$ & $\begin{array}{c}\text { My } \\
\text { (tonf.m) }\end{array}$ & $\begin{array}{c}\theta y \\
(\times 0.01)\end{array}$ & $\begin{array}{c}\mathrm{Mu} \\
\text { (tonf.m) } \\
\end{array}$ & $\mid \begin{array}{l}K e ： \text { 弾性剛性 } \\
M y ： \text { 全望性モーメント }\end{array}$ \\
\hline No.1 $\sim 6,8$ & 35.6 & 180 & 0.68 & 272 & $\theta y: M y に$ 对応す万弾性部材角 \\
\hline 0.7 & 44.8 & 216 & 0.64 & 340 & Mu : 最大モーメント \\
\hline
\end{tabular}
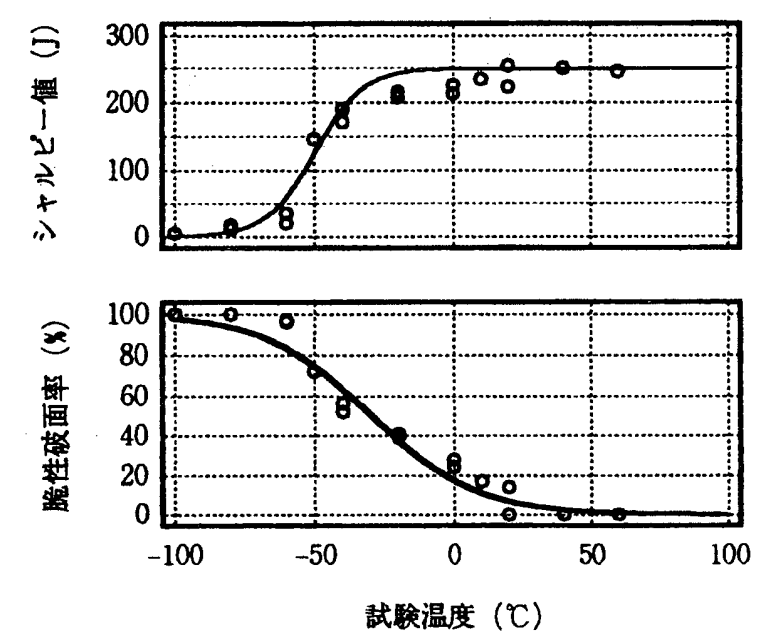

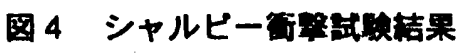




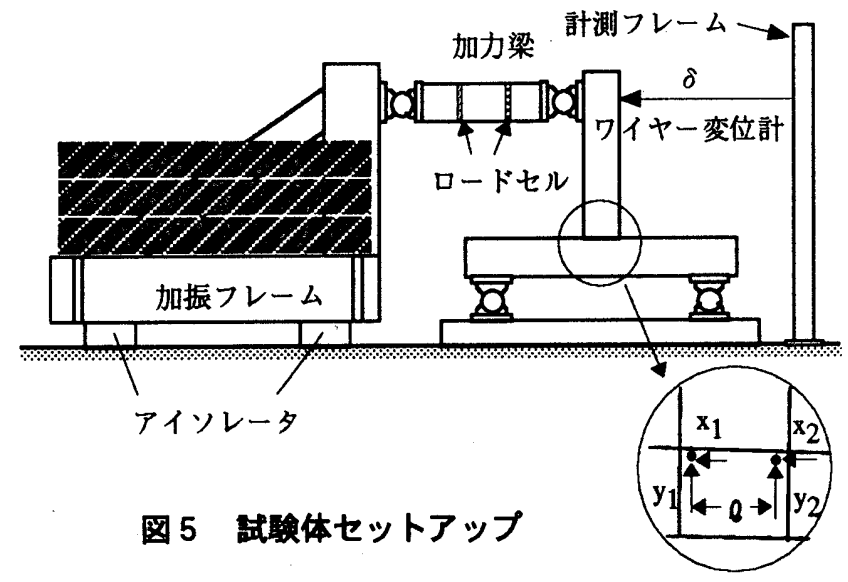

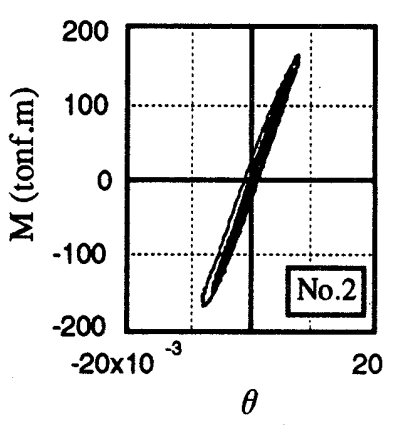

図 6 唯性加振における 粱端モーメントと部材角

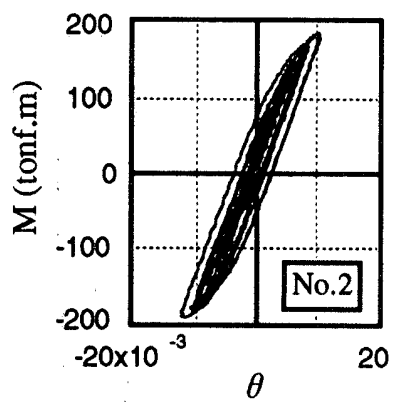

图 7 嚁望性加振における 梁端モーメントと部材角
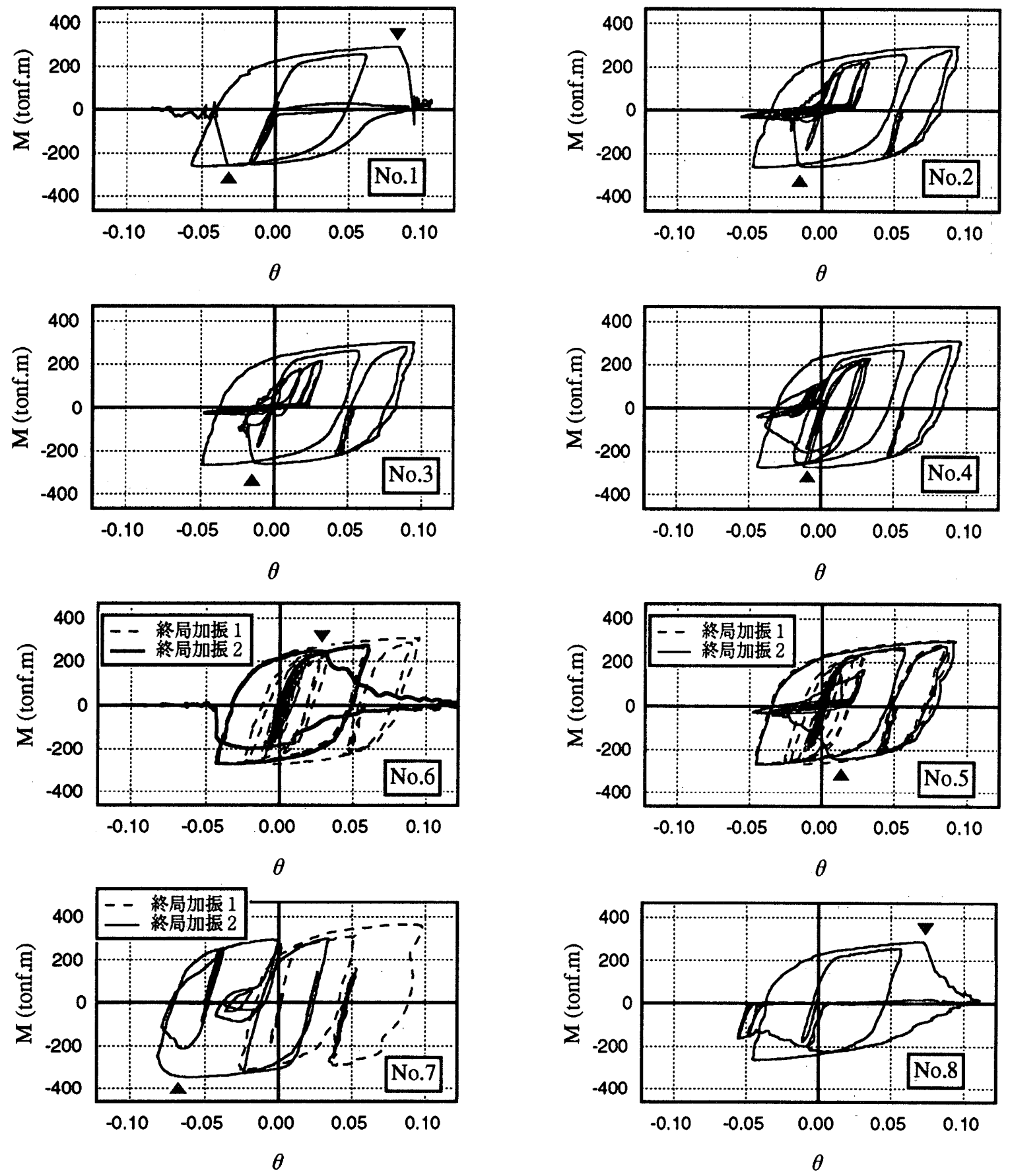

图8 終局加振における梁端モーメントと部材角の䁌係 


\section{2 实絤結果概要}

各試験体の終局挙動、酎力および変形能力に関する結果を表 5 に まとめる。初期状態における振動系全体の固有周期は䄪 $0.6 \mathrm{sec}$ であ り、これは神戸海洋気象台NS波を入力した場合に充分なエネルギー 入力が得られる周期である ${ }^{6)}$ 。

図 9 に示すように、繰り返し荷重を受ける龬部材の荷重変形曲線 を、新たな荷重領域に到達する毎につなげていくことによって骨格 曲線が得られる ${ }^{11)}$ 。ここでは、弾性加振から終局加振までの全載 荷履歴について、荷重変形関保を分解し骨格曲線を抽出した。表中 の全塑性モーメント $M y^{\prime}$ 及び $M y^{\prime}$ に対応する弾性部材角 $\theta y^{\prime}$ は、骨 格曲線からGeneral-Yield法（図10参照）によって求めた実験値であ る。

弾性㴊性については、実験値は表 4 中の計算値とよく一致してい る。一方、全塑性モーメントについては、実験値 $M y^{\prime} か ゙$ 計算値 $M y を$ 上回っており、弾性部材角の計算值 $\theta y$ が実験値 $\theta y$ 'に対して小さ い值となっている。このため、梁の酎震性能を無次元化量によって 評価する際、My及び $\theta y$ を基準とした場合には部材性能を過大評価
する危険がある。このため、本論文においては $M y^{\prime}$ の平均値 $M y^{\prime \prime}$ (No7については My')、My'”弾性剛性の計算值から得られる弾 性部材角 $\theta y^{\prime \prime}$ を無次元化する際の基準値として用いる。

耐力上年率 $: \alpha=\frac{M_{u}}{M_{y}^{\prime \prime}}$

$M u:$ 最大モーメント

骨格曲線における累積塑性変形倍率： $\quad \eta_{s}=\frac{\vartheta_{s}}{\vartheta_{y}^{\prime \prime}}-1$

$\vartheta_{s}:$ 図 9 中に示す骨格曲線上での最大部材角

Wpは、弾性加振から終局加振中の梁端破壊が生じた時点までの 全履歴において梁が吸収した塑性エネルギーであり、梁に作用する せん断力と（1）式に示す梁の変形から求めた值である。 $s W p$ は骨 格曲線部分で吸収した塑性エネルギーであり、図 9 中網掛けの部分 の面積に相当する。

表 5 実験結果

\begin{tabular}{|c|c|c|c|c|c|c|c|c|c|c|c|c|}
\hline 試験体 & $\begin{array}{l}\text { 加振 } \\
\text { 方向 }\end{array}$ & $\begin{array}{c}\text { 脆性破面率 } \\
(\%) \\
\end{array}$ & $\begin{array}{c}\mathrm{T} \\
(\mathrm{sec}) \\
\end{array}$ & $\begin{array}{c}K \mathrm{e}^{\prime} \\
\text { (tonf/cm) } \\
\end{array}$ & $\begin{array}{c}M y^{\prime} \\
\text { (tonf } \cdot m \text { ) }\end{array}$ & $\begin{array}{c}\theta y^{\prime} \\
(\times 0.01) \\
\end{array}$ & $\begin{array}{c}M u^{\prime} \\
\text { (tonf } \cdot \mathrm{m} \text { ) } \\
\end{array}$ & $\begin{array}{c}\theta \max \\
(\times 0.01) \\
\end{array}$ & $\alpha$ & $\eta s$ & $\begin{array}{c}W p \\
\text { (tonf } \cdot \mathrm{m}) \\
\end{array}$ & $\begin{array}{c}s W p \\
(\text { tonf } \cdot \mathrm{m} \text { ) } \\
\end{array}$ \\
\hline No.1 & $\begin{array}{l}+ \\
-\end{array}$ & $\begin{array}{l}55 \\
30 \\
\end{array}$ & 0.66 & 31.5 & 194 & 0.83 & $\begin{array}{l}290 \\
265 \\
\end{array}$ & $\begin{array}{l}8.4 \\
5.7 \\
\end{array}$ & $\begin{array}{l}1.46 \\
1.33 \\
\end{array}$ & $\begin{array}{l}15.1 \\
11.5 \\
\end{array}$ & 71.3 & 50.8 \\
\hline No. 2 & $\begin{array}{l}+ \\
-\end{array}$ & $\begin{array}{c}- \\
12 \\
\end{array}$ & 0.64 & 32.3 & 202 & 0.84 & $\begin{array}{l}298 \\
267 \\
\end{array}$ & $\begin{array}{l}9.4 \\
4.8 \\
\end{array}$ & $\begin{array}{l}1.50 \\
1.34 \\
\end{array}$ & $\begin{array}{l}16.2 \\
10.1 \\
\end{array}$ & 99.3 & 53.0 \\
\hline No.3 & $\begin{array}{l}+ \\
- \\
\end{array}$ & $\begin{array}{l}- \\
0 \\
\end{array}$ & 0.64 & 31.0 & 206 & 0.89 & $\begin{array}{l}301 \\
268 \\
\end{array}$ & $\begin{array}{l}9.5 \\
4.9 \\
\end{array}$ & $\begin{array}{l}1.51 \\
1.35 \\
\end{array}$ & $\begin{array}{l}16.3 \\
10.2 \\
\end{array}$ & 100.2 & 53.5 \\
\hline No.4 & $\begin{array}{l}+ \\
- \\
\end{array}$ & 0 & 0.63 & 32.5 & 209 & 0.86 & $\begin{array}{l}312 \\
277 \\
\end{array}$ & $\begin{array}{l}9.6 \\
4.4 \\
\end{array}$ & $\begin{array}{l}1.57 \\
1.40 \\
\end{array}$ & $\begin{array}{l}16.3 \\
10.2 \\
\end{array}$ & 121.8 & 53.3 \\
\hline No.5 & $\begin{array}{l}+ \\
- \\
\end{array}$ & - & 0.63 & 32.8 & 193 & 0.79 & $\begin{array}{l}299 \\
271 \\
\end{array}$ & $\begin{array}{l}9.0 \\
4.5 \\
\end{array}$ & $\begin{array}{l}1.51 \\
1.36 \\
\end{array}$ & $\begin{array}{l}15.4 \\
12.5 \\
\end{array}$ & 204.7 & 54.2 \\
\hline No.6 & $\begin{array}{l}+ \\
- \\
\end{array}$ & $\begin{array}{l}0 \\
0 \\
\end{array}$ & 0.61 & 33.3 & 206 & 0.83 & $\begin{array}{l}307 \\
275 \\
\end{array}$ & $\begin{array}{l}9.5 \\
4.3 \\
\end{array}$ & $\begin{array}{l}1.54 \\
1.38 \\
\end{array}$ & $\begin{array}{l}16.3 \\
11.9 \\
\end{array}$ & 176.2 & 55.8 \\
\hline No.7 & $\begin{array}{l}+ \\
- \\
\end{array}$ & - & 0.54 & 41.3 & 253 & 0.82 & $\begin{array}{l}367 \\
349 \\
\end{array}$ & $\begin{array}{l}9.7 \\
8.2 \\
\end{array}$ & $\begin{array}{l}1.45 \\
1.38 \\
\end{array}$ & $\begin{array}{l}14.8 \\
15.3 \\
\end{array}$ & 162.0 & 72.1 \\
\hline No.8 & + & $\begin{array}{r}0 \\
-\end{array}$ & 0.61 & 33.2 & 181 & 0.73 & $\begin{array}{l}288 \\
264 \\
\end{array}$ & $\begin{array}{l}8.1 \\
4.9 \\
\end{array}$ & $\begin{array}{l}1.45 \\
1.33 \\
\end{array}$ & $\begin{array}{l}14.1 \\
10.9 \\
\end{array}$ & 63.9 & 45.3 \\
\hline
\end{tabular}

$\mathrm{T}$ : 初期状態における振動系の固有周期

$K e^{\prime}:$ 弾性剛性

$M y^{\prime}:$ 全塑性モーメント

$\theta y^{\prime}:$ 全塑性モーメントに対応寸る弾性部材角

$M u^{\prime}:$ 最大モーメント

$\theta \max :$ 最大部材角

$\alpha:$ 耐力上昇率

$\eta \mathrm{s}:$ 骨格曲線に扔ける累積塑性変形倍率

Wp :梁端破壊に至るまでの全履歴において梁が吸収した塑性エネルギー

$s W p:$ 骨格曲線部分において梁が吸収した塑性エネルギー

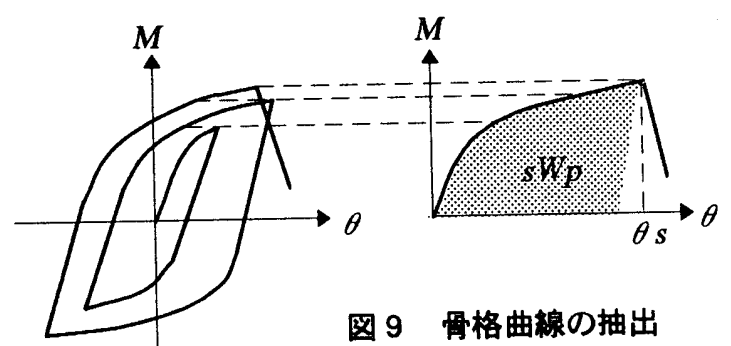

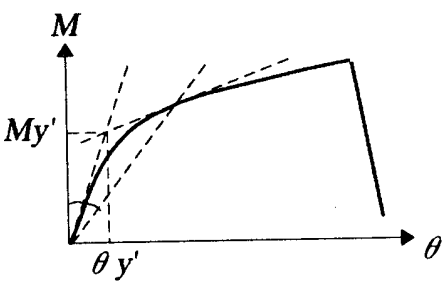

图10 General-Yield法 


\section{3 破断状況}

梁フランジの破壊状況には以下の 2 タイブが見られた。

Type1: (試験体No.1,2)

スカラップ底近傍から発生した延性き裂が成長する過程で脆性破 壊に転化し、脆性破面が母材中を伝播した。また、エンドタブ近傍 の溶接止端部からも延性き裂が発生し、母材中にき裂の進展が認め られた。写真 1 に試験体No.1の破断面の様子を示す。

Type2: (試験体No.3 8)

スカラップ底近傍及びエンドタブ近傍の溶接止端部（ノンスカラッ プタイプのものは溶接止端部のみ）から延性き裂が発生し、各々が 母材中を進展、合体してフランジ全面に延性破面を形成した。写真 2 に試験体No.4の破断面の様子を示す。

延性破面に観察されるディンプルは、図11に示す機構によって形 成される ${ }^{12)}$ 。このため、ティンフルパターンと延性亀裂の進展方 向により、梁端に生じた応力状態が推定できる。脆性破面が認めら れたNo.1 と全面延性破面となったNo5について、破面のパターン、 板厚方向の延性龟裂の進展方向、及び推定される応力方向を図 12 に 示す。No.5の破面が水平に対して $45^{\circ}$ 方向であるのに対し、No.1で は、シヤーリップ部分を除くと、水平に対して $15^{\circ}$ 方向に破面が進 展している。このことから、No.1とNa5では図12中に示すように梁 端フランジにおける応力方向が異なっていたことが分かる。

柱梁接合部のスカラップ部分においては、ウェブが負担していた せん断力の一部がフランジに伝わり、梁端フランジに局所的な面外 曲げが生じることが従来から指摘されている ${ }^{7)}$ 。前述のスカラッ プ有無による応力方向の变化は、この知見と合致するものである。 多軸応力状態における鋼材は、降伏応力の上昇によって脆性破壊が

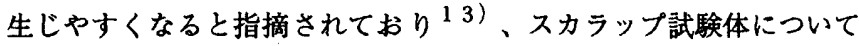
は、脆性破壊しやすい応力状態が成立していたと考えられる。

しかし、Type1の破堘を生じた試験体においても、本実験の場合 は延性破面が破断面の45\%以上を占めており、断面のくびれも認め られる。又、いずれの試験体も塑性化領域が水平材の表面から90〜 $100 \mathrm{~cm}$ 程度（梁の長さの約 $1 / 3$ ）広がっており、酎力上昇率は 1.4 以 上を示している。以上の点から、いずれの試験体も十分な強度と変 形能力を発揮した後に破壊しており、その部材性能は母材金属の延 性的な破壊条件に支配されたと考えられる。

\section{4 酮荷速度}

標準試験体Na.2について、終局加振時の試験体頂部の速度及び梁 端部の歪集中箇所における歪速度を図13に示す。試験体頂部の最大 速度は160～170kine程度であり、他の試験体も同レベルであった。 最大歪速度は、試験体間の歪集中の程度によって異なり、50～90\%/ secであった。このような載荷条件においても、試験体は高い変形能 力を示した後に延性的に破壊しており、実大部材を高速載荷したこ とによる変形能力の低減効果は現れなかったと考えられる。

\section{5 兴格曲線}

既往の研究により、骨格曲線は一方向載荷の荷重変形曲線によっ て置換できるといわれている ${ }^{11}$ ）。図14に、骨格曲線をパラメータ 毎に比較して示す。図中には数値積分法による予測値を併せて示し ている。予測值の計算の際には、引張側には素材引張試験から得ら

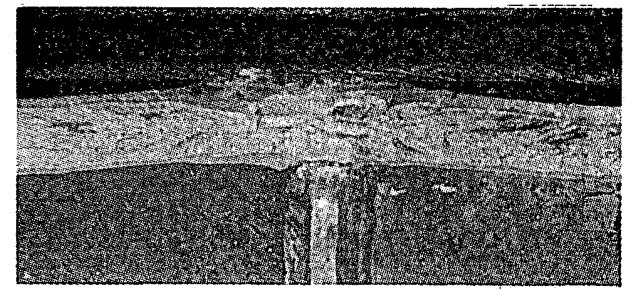

写真 1 試験体No.1の破断面 (Type1)

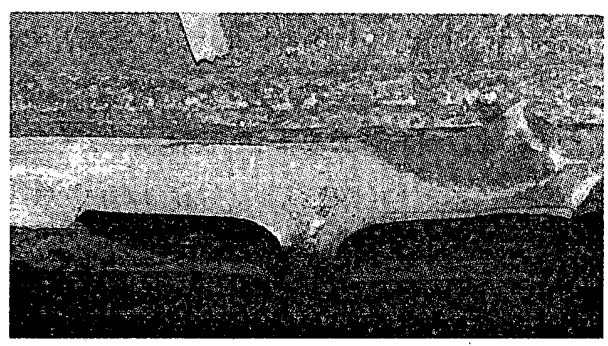

写真2 武験体No.4の破断面 (Type2)

(1)
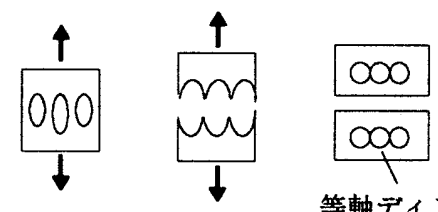

(2)
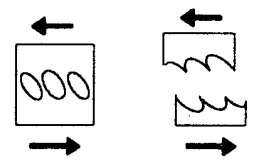

等軸ディンプル

(3)
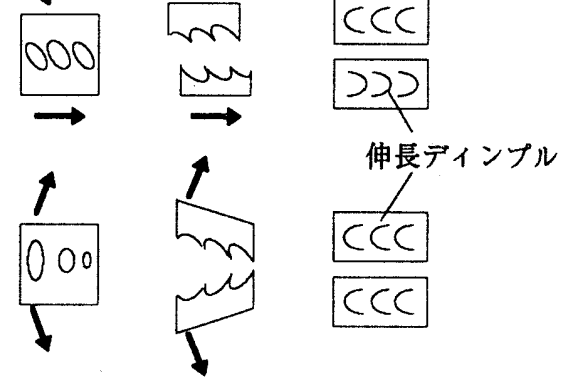

図11 ティンプルの形成機構!2)
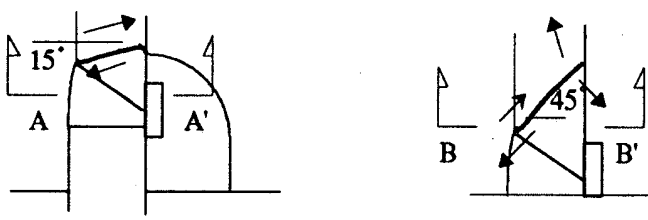

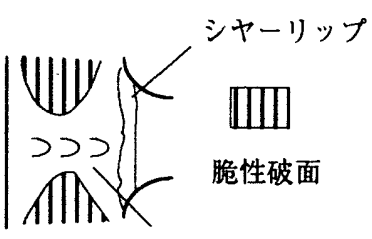

A-A' 伸長ディンプル $\left|\begin{array}{l}\supset \supset c c \\ \supset>c c \\ \supset \subset c \mid\end{array}\right|$

伸長ディンプル B-B

(2) 試験体No.5
图12 破面の進展方向とティンプルパターン 
れた公称応力ー公称歪関係を入力した。圧緮側については、引張試 験のアータを下式によって圧絔応力下の公称応カー公称歪関係に変 換したものを用いた。

圧縮側の公称歪： $\varepsilon_{c}=\frac{-\varepsilon_{t}}{1+\varepsilon_{t}}$

圧緶側の公称応力： $\sigma_{c}=-\left(1+\varepsilon_{t}\right)^{2} \cdot \sigma_{t}$

(6)

$$
\begin{aligned}
& \varepsilon_{t}: \text { 引張側の公称歪 } \\
& \sigma_{t}: \text { 引張側の公称応力 }
\end{aligned}
$$

いずれの試験体も、実験值が予測耐力を 1 割程度上回っており、 载荷速度の影響が現れている可能性がある。

梁が同一断面の試験体については、接合詳細の違いに関わらず骨 格曲線はほほ一致し、最大耐力、最大変形ともに有意差は認められ ない。

\section{6 虽歴吸収エネルギー}

試験体の梁端破壊に至るまでに吸収した塑性エネルギーWpを $\left(M^{\prime \prime} y \cdot \vartheta " y\right)$ で無次元化することによって等価累積塑性変形倍率 ${ }^{\circ} \eta$ が得られる。つまり、 塑性系に置換した場合の累積塑性変形倍率に相当する。図 15 に ${ }_{E} \eta$ をパラメータ毎に比較して示す。図中には骨格曲線部分で吸収

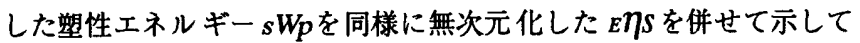
いる。

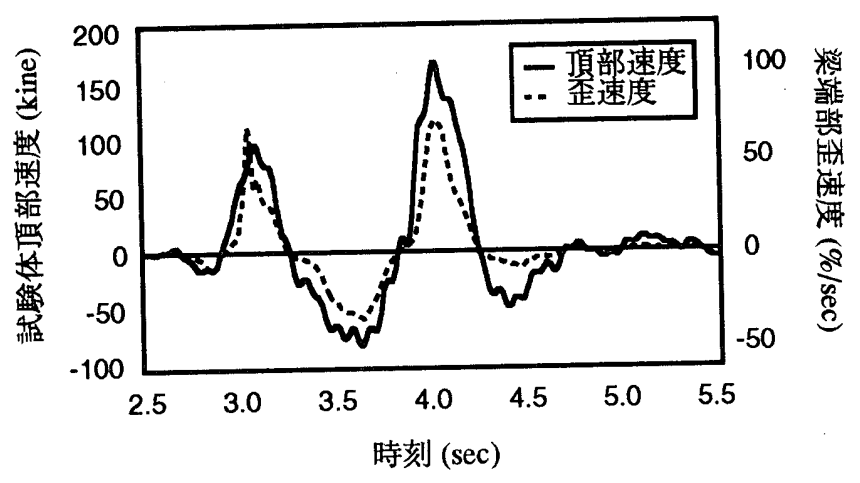

図13 載荷速度

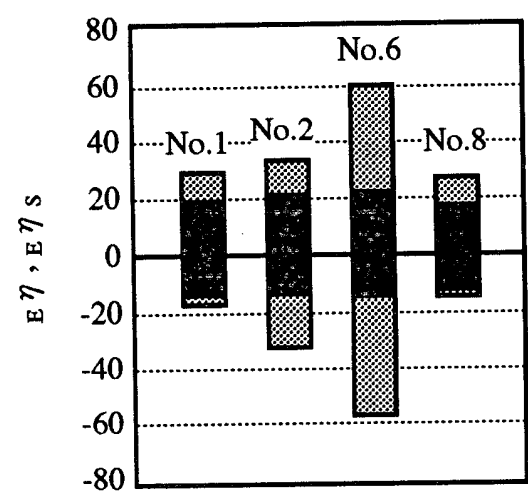

（1）ウェプのモーメント負担の影響

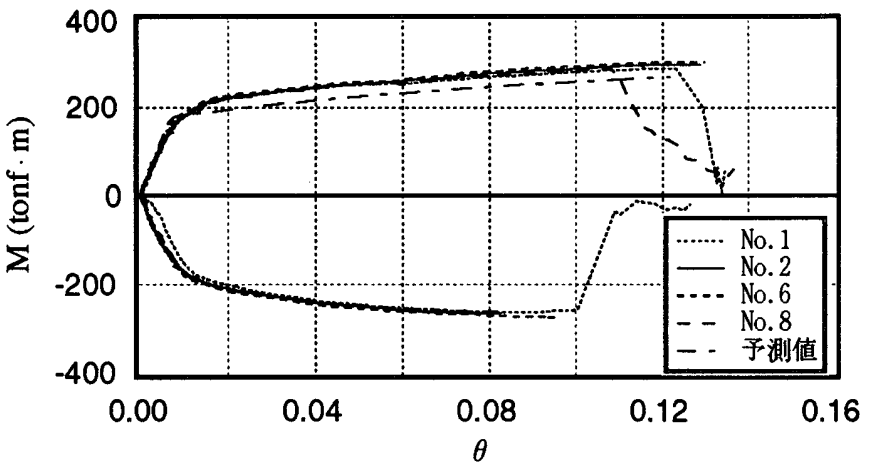

(1) ウェブのモーメント負担の影響

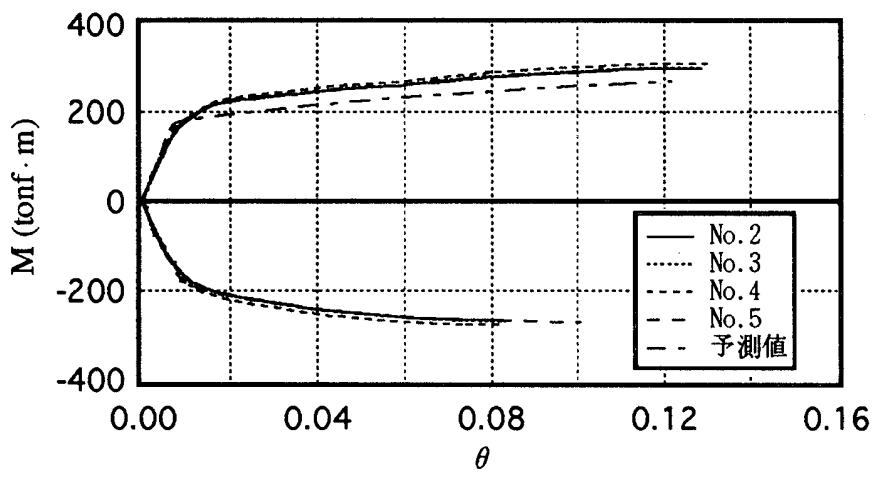

(2) スカラップ形状の影響

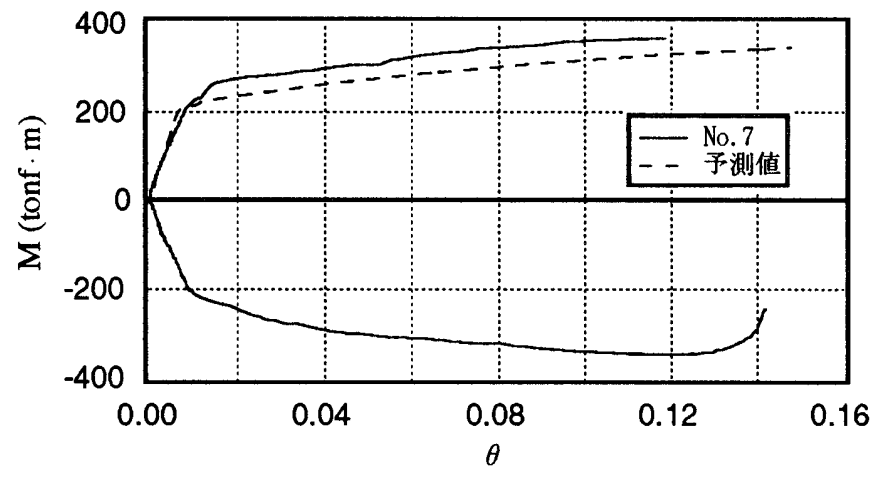

(3) 梁厚板

図14 骨格曲線

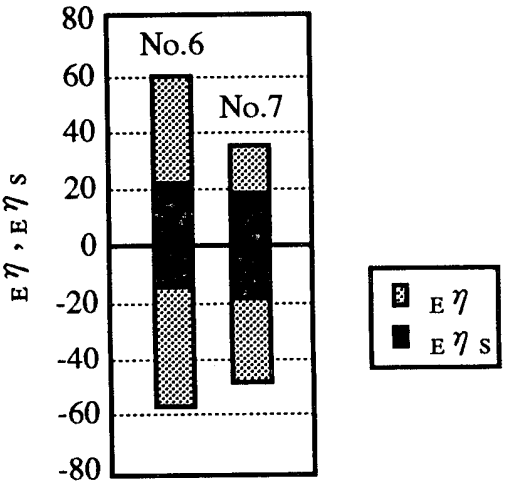

（3）梁板厚の影響

图15 等価累積塑性変形倍率 


\section{(1) ウェフのモーメント負担の影響}

ウェブのモーメント負担が大きいと思われるものほど、全エネル ギー吸収量が大きくなっている。ウェブのモーメント負担が小さい 場合、フランジへの応力集中、歪集中が生じることが予想され、こ のことが試験体のエネルギー吸収量に影榔を及はしたと考えられる。

(2) スカラップ形状の影響

スカラップを有する試験体については、エネルギー吸収量にスカ ラップ形状の違いによる有為差は認められない。これは、材料の䩗 性が高く、幾何学的形状の不連 続に対して感受性が低かったためと 考えられる。No.5のノンスカラップ試験体は他の試験体より全エネ ルギー吸収量が大きくなっている。

(3) フランジ板厚

フランジが厚板である試験体No.7は、No.6よりもエネルギー吸収 量がやや小さくなっている。しかし、No.7は全面延性破壊しており、 本実験では脆性破壊への転化を促寸効果としての板厚の影響は現れ ていないと考えられる。

\section{4 結期}

兵庫県南部地震において、龬構造剛接接合部が嚗された負荷状態 を忠実に再現することを狙いとして、慣性加力装圈を用いた赛大振 動台実験を行った。試験体は角形鋼管柱にH形梁を接合して製作し、 パラメータとして、梁ウェブのモーメント負担、スカラップ形状、 及び梁の板厚を設定した。神戸海洋気象台NS波に加速度倍率を乗じ て作成した地震波を入力し、梁端部の破壊を再現した。得られた䊅 果は以下の通りである。

（1）試験体の破壊状況は、全断面が延性破面になったものと、一部 に脆性破面が認められたものがあった。しかし、いずれの試験体も 十分な強度と変形能力を発揮した後に破壊しており、その部材性能 は舟材金属の延性的な破壊条件に支配されたと考えられる。

（2）载荷速度は試験体頂部で約160kineであり、梁端部における最大 昰速度は50 90\%/secであった。この条件下においても、試験体は高 い銒力と変形能力を示した後に破壊しており、実大部材を高速載荷 したことによる変形能力の低隇奻果は現れなかったと予想される。 (3) 材料の勒性が高い場合は形状不連続に対する感受性が低く、従 来型スカラップと改良型スカラップの相違が部材の酎震性能に及は す影響は小さい。また、材料の鞓性が高い場合はフランジ板厚が厚 い場合でも延性破壊し、履歴吸収エネルギーの低減には至らない。 本報では実験結果の概要を報告した。今後の課題としては、設定 したパラメータと梁フランジに生じた荷重効果との関保に関する定 量的な検討が挙げられる。又、本報の実験における試験体の靭性が 高かったために、その影響が顕在化しなかった要因についても、更 に検討を進める必要がある。

\section{考文献}

1）日本建築学会近畿支部鉄骨構造部会：1995年兵庫県南部地震鉄 骨造建築物被害調查報告書、1995.5

2) 加藤勉、森田耕次：極厚棈造部材の脆性破俵、日本建築学会論 文報告集、No.156, pp1 10,1969.2

3）矢部喜堂、坂本真一、中込忠男：梁スカラップの有無が箱型断 面柱に溶接接合される $\mathrm{H}$ 形鋼梁端部の力学的性状に及はす影艟、日
本建築学会構造系論文報告集、No.440,pp125～132,1992.10

4）中島正爱、吹田啓一郎、森迫清貴：通しタイヤフラム形式で接 合されるH形梁の塑性変形能力に関する実大実験、（その 5 工場 溶接タイプ、材料B6による実験 [2]）、日本建築学会大会学術講演梗 概集、c-1,pp337 338, 1997.9

5 ）加村久哉、岡本晴仁、伊藤茂樹、本間厚子：強震時の央速度が 龬構造物の柱梁接合部に与える影響に関する解析的検討、（その1

梁端に発生する歪速度の推定)、日本建筑学会大会学術講演 梗概 集、c-1, pp425 426, 1997.9

6）秋山宏、山田哲、箕输親宏他 3 名：慣性加力装置を用いた構造 要素の実大掁動実験方法、日本建築学会構造系論文報告集、No.505, 1998.3

7）園田隆一、金谷弘、田淵基嗣、田中丈之：鋼管柱、梁接合部の 力学的性状に与える接合詳細の影響、一その 10 梁フランジの 2 次曲げの影響一、日本建築学会大会学術講演梗概集、pp1247 1248, 1993.9

8）中込忠男、藤本盛久他 3 名：500 $/ \mathrm{mm} 2$ 級龬の板厚、強度と必 要鞄性、日本建筑学会大会学術講演梗概集、c-1, pp619 620,1995.8

9）田淵基跼、金谷弘、田中丈之、園田隆一：角形鋼管柱・梁仕口 溶接部における改良型スカラップ工法の提案、鋼構造シンポジウム 論文集、第 1 巻、pp65 72,1993.7

10）坂本真一、矢部寠堂他：はりスカラップを有しない柱はり溶接 接合部の力学的性状、その1、その 2、日本建築学会大会学術講演 梗概集、c-2,pp1591 1594,1990.10

11）加藤勉、秋山宏：構造部材の耐力（その 4 ）、日本建築学会論 文報告集、No.151,pp15２0,1968.9

12）黑木剛司郎、大森宫次郎、友田陽：金属の強度と破壊 第 2 版、 pp44, 森北出版

13）金沢武：軟鋼の脆性破壊に就て（第 1 報）、造船協会論文集、 No.89, pp83 $\sim 94$

\section{㩆辞}

本研究は、科学技術庁官民特定共同研究「阪神淡路大震災被害に 基づく銅構造建築物の終局酎震性能に関する研究」の一貫として行 われた。研究推進は下記の委員会組織によって行った。

「銅構造終局酎震性研究推進委員会」

委員：東京大学（秋山宏（委員長）、桑村仁、山田哲、高橋誠）、 科学技術庁防災科学技術研究所（小川信行、箕輪親宏）、科学技術 宁金属材料研究所（松岡三郎、竹内说男）、東京理科大学（寺本隆 幸）、住友金属（加藤征宏、大竹章夫、福田浩司）、清水建設（矢 部喜堂、真瀬伸治、寺田岳彦) 、大成建設（小倉桂治、泉満、辻田 修、成原弘之）、東急建設（木村克次、公塚正行、末岡利之、小駒 勲、千菜隆史）、三菱建設（田中宏志、時本和則、藤原秀雄）、日 建設計（北村春幸、向野聡彦）、フジタ（三山剛史）、日本ドライ ブイット（矢幡秀介、村谷昌夫）

(1997年12月 9 日原稿受理，1998年 5 月 8 日採用淶定) 